\title{
Assessment Of The Bacteriological Quality Of Ice Cream Offered For Public Consumption In Bauchi. Nigeria.
}

\author{
${ }_{\text {... Moshood A. Yusuf, }}^{2,}$ TengkuHaziyamin Abdul ${ }^{3,}$ Tengku Abdul Hamid, \\ ${ }^{4}$ Mr. Moshood A. Yusuf \\ Department of Biotechnology, Kulliyyah of Science, International Islamic University Malaysia, Bandar \\ InderaMahkota, Jalan Istana, 25200 Kuantan, Malaysia. (+60169874458) \\ TengkuHaziyamin Abdul Tengku Abdul Hamid ${ }^{2}$ \\ Department of Biotechnology, Kulliyyah of Science, International Islamic University Malaysia, Bandar \\ InderaMahkota, Jalan Istana, 25200 Kuantan,
}

\begin{abstract}
: 30 samples of locally produced and industrially produced ice cream were examined for the presence of bacteria contaminants. Bacteria count was carried out on the different samples using pour plate method. Isolates were identified using standard procedure. Different types of bacteria isolated include Bacillus cereus, Staphylococcus aureus, Streptococcus pyogenes, Escherichia coli and Salmonella typhi. The total bacteria count per $m l$ of the locally produced ice cream sample range from $1.4 \times 10^{4}-3.0 \times 10^{4}$ and the total bacteria count per $\mathrm{ml}$ of the industrially produced ice cream sample range between $3.0^{\times} 10^{3}$ $8.8 \times 10^{3} \mathrm{cfu} / \mathrm{ml}$. The mean count of locally produced and industrially produced ice cream was $2.0 \times 10^{4}$ and $5.3 \times 10^{3}$ respectively, therefore industrially produced ice cream is more hygienic than locally produced ice cream.The presence of possible pathogenic organisms in the analyzed ice-cream sample should be viewed with concern by the consumers, producing company and the Government since food poisoning by Staphylococcus sp, Bacillus sp and Salmonella sp is possible through consumption of contaminated ice-cream.
\end{abstract}

Keywords: ice cream, mean count, pathogenic organisms

\section{Introduction}

Milk is an opaque white liquid produced by the mammary gland of female mammals. It provides the primary source of nutrition for newborn mammals before they are able to digest other types of food. The exact components of raw milk vary by species, but it contains significant quantity of saturated fat, protein and calcium as well as vitamin C.Cow milk has a pH ranging from 6.4 to 6.8 making it slightly acidic. Several animals produce milk for human consumption, although the cow is by far the most important in commercial term [1]. The milk is perishable thereby necessitating it's immediate consumption as fresh milk can be processed into other products like ice-cream, yoghurt, cheese, butter which have improved keeping qualities. Ice cream is a product of a milk consisting milk, sweetening and stabilizing agents together with flavoring and coloring matter [2]. It is a product that has wide patronage from infants, youth, adolescent and adult [3]. There are numerous variables that must be controlled accurately during processing to obtain a high quality ice cream with the required taste, flavor, viscosity, consistency and appearance. Handling and storage condition are some of these variables because they affect the physical, chemical and microbial quality of product. The methods employ in the sale of ice cream are of different categories. It could be sold in open containers at retail outlets or in packages which may then be distributed manually in scoops, cones, or sundaes across the counter [4]; [5]; [6] and [7].

Most ice creams become contaminated with microbes during production, transit, and preservation. Disease outbreak in many countries of Asia, Europe, and North America is as a result of consumption of ice cream contaminated with microbial pathogens during the processing stage [8]; [9] and [10]. In Previous reports, high microbial loads in ice cream samples obtained from patisseries in Turkey was observed [11; [12]; [13]; [14]; [15]; [16]; [17] and [18]. The consumption of ice-cream is higher among children of vulnerable age groups therefore there is a need to maintain a high microbiological safe standard [6]. The possibility of acquiring food borne diseases by infant, children, elderly people and immunosuppressed patients from this product is likely [6] and [19].A relatively low storage temperature and pasteurization step during its processing are considered to eliminate most of the pathogenic microorganisms. However, the addition of contaminated ingredients, improper handling and the use of improper storage temperatures are factors that contribute to the potential hazard of the 
finished products especially during processing after pasteurization processes. This is particularly of interest during soft ice cream preparation since the point of sale happens to be its final stage of production [20].

Other possible sources of microorganisms in ice-cream have been reported to include raw materials used for the composition of ice-cream mix such as separated milk and milk powder cream, flavoring and coloring substances and stabilizers [21] and from air during processing [22].Food spoilage is a predominant problem in African countries, Nigeria inclusive. It is generally stored by refrigeration, but the original taste and flavor does not last very long. Proper handling and storage of ice-cream helps to prevent its spoilage and the incidence of food borne illness, thereby increasing its shelf life. Therefore the aim of this research is to determine the bacteriological quality of ice cream offered for public consumption; to understand the difference in the microbiological qualities between local and industrially produced ice creams.

\subsection{Sample collection}

\section{Materials And Methods}

A total of 30 samples, 20 samples of locally produced ice -cream and 10 samples of industrially produced ice-cream were purchased from hawkers and retail outlets within Bauchi metropolis respectively. The samples were collected in a sterile container and brought to the laboratory immediately for proper analysis.

\subsection{Preparation Of Serial Dilution}

$1 \mathrm{ml}$ of each ice- cream sample was a pipette out aseptically and transferred into a sterile test- tube containing $9 \mathrm{ml}$ of peptone water to give a dilution of $1: 10$, from this dilution, a serial dilution of up to $10^{-3}$ was carried.

\subsection{Bacteriological Examination Of Samples Collected}

\subsubsection{Primary Isolation Of Bacteria From Samples}

Using the pour plate technique, the prepared samples of concentration range $10^{-1}$ and $10^{-2}$ were used for inoculation. $1 \mathrm{ml}$ of each of this dilution was inoculated on nutrient agar, McConkey agar and Salmonella Shigella agar respectively in duplicate. It was rocked and allowed to solidify, inverted to prevent condensation of moisture on the surface of the agar and were incubated at $37^{\circ} \mathrm{c}$ for $18-24$ hours. At the end of incubation, the number of colonies was counted with the aid of a colony counter. Average of duplicate plates were counted and recorded as the numbers of colony forming unit (cfu/ ml) of each ice-cream sample. The bacteria plate counts per ml were recorded using $\frac{n}{V \times R}$

Where

$\mathrm{n}=$ Number of colonies

$\mathrm{r}=$ Dilution factor

$\mathrm{v}=$ Value of the particular dilution being put on the medium.

\subsection{Purification And Storage Of Isolates}

Bacterial colonies that appeared on the primary isolation plates were subcultured onto fresh nutrient agar plates to obtain pure cultures of the different isolates. The final cultures containing discrete colonies were transferred onto slants made with McCartney bottles and test tubes containing nutrient agar. The slants were stored in the refrigerator at $4^{0} \mathrm{c}$ for further studies outlined below.

\subsection{Characterization And Identification Of Isolates}

The bacteria isolates from different samples were grouped on the basis of colonial morphology. The criteria used, where the size of the colony, color, surface, edge, slope and elevation as described by [23].

\subsubsection{Microscopic Examination Of The Isolates}

Smears of each of the different bacterial isolates was made with a clean- grease free slide and air dried. These were directly observed under the microscope using the oil immersion objective (x100).The bacterial isolates were stained using Gram's Method of staining to study the morphological appearance of the cell as well as their Gram reactions (Whether they are Gram positive or Gram negative) and cell arrangement.Gram positive cells retained the purple color of the initial dye while the Gram negative cells retained the pinkish-red color of the counter stains [24].

\subsubsection{Biochemical Tests}

Biochemical tests were performed to confirm the identity of the isolated bacteria 24 hours old cultures were used to perform the biochemical test. [25]. 


\section{Results}

A total of 30 ice-cream samples from Bauchi metropolis were examined for bacteria contamination. Results were compiled separately for 20 samples of locally produced ice-cream and 10 samples of industrially produced ice-cream.Fig. 1 shows the bacteria plate counts per $\mathrm{ml}$ of locally produced ice-cream in the range of $1.4 \times 10^{4}-3.0 \times 10^{4}$ and industrially produced ice-cream in the range of $3.0 \times 10^{3}-8.8 \times 10^{3}$.Table 2 shows the mean bacteria count obtained from both locally produced and industrially produced ice-cream samples. The locally produced ice-cream sample had the higher mean count of $2.0 \times 10^{4}$ and industrially produced ice-cream with a mean count of $5.3 \times 10^{3}$ Presented on Fig. 3 is the frequency and percentage occurrence of the different bacteria isolated from both locally produced and industrially produced ice-cream samples. In locally produced ice-cream Bacillus sp occurred in 5 samples, Staphylococcus $S p$ occurs in 3 samples. Streptococcus $s p$ in 2 samples. Escherichia coli in 7 samples and Salmonella sp in 3 samples .Escherichia coli had the highest frequency with the percentage occurrence of $35 \%$ and streptococcus sp had the lowest frequency with percentage occurrence of 10\%.In industrially produced ice-cream, Staphylococcus sp occurs in 6 samples while Streptococcus sp was found in 4 samples with a percentage occurrence of $60 \%$ and $40 \%$ respectively.

Figure 1 is a bar chart showing percentage occurrence of bacteria isolated in locally produced ice-cream.

Figure 2 is a bar chart showing percentage occurrence of bacteria isolated in industrially produced ice-cream.

\section{Enumeration of total bacteria counts}

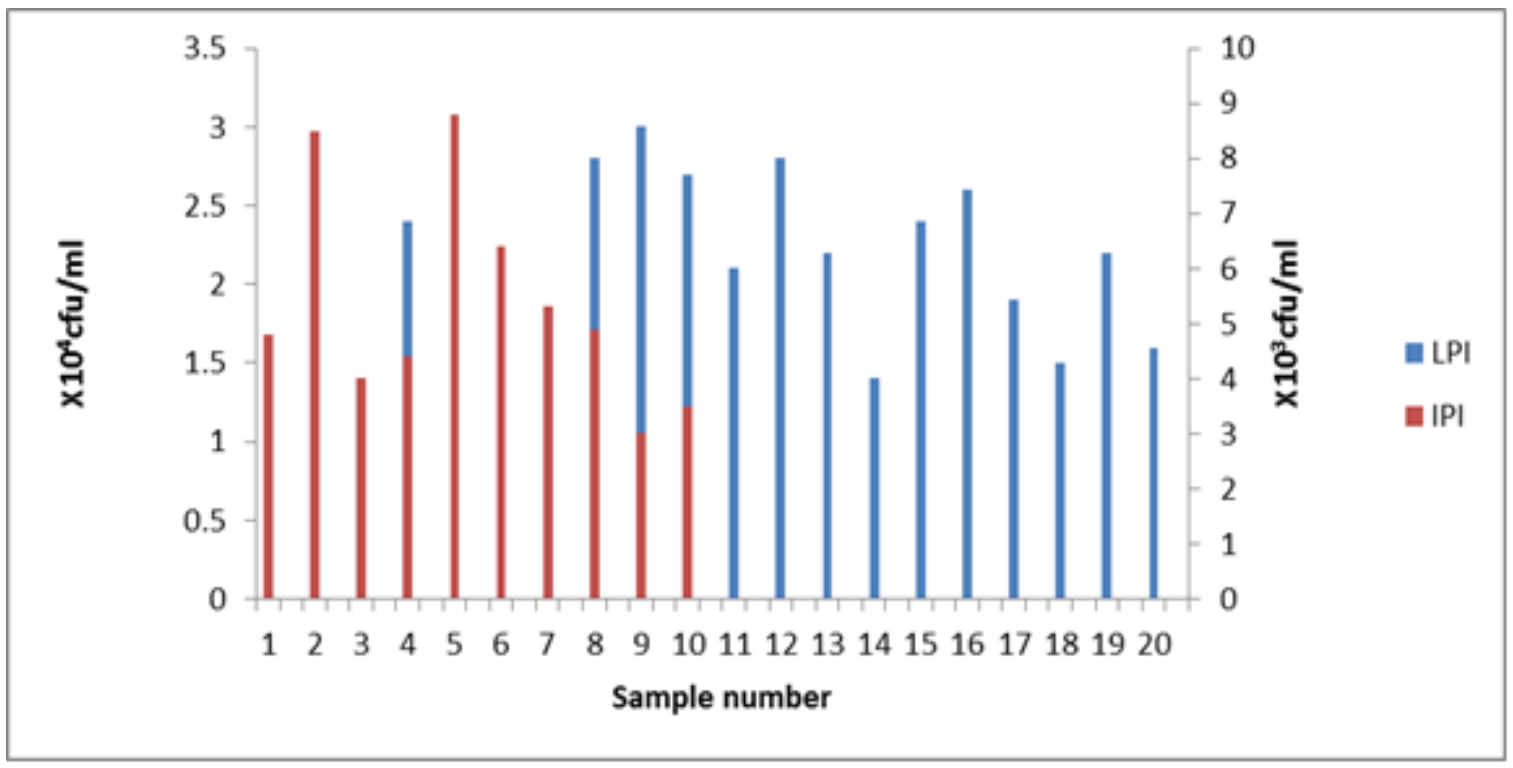

Fig. 1: Bacteria plate counts per $\mathrm{ml}$ of 20 locally produced ice-cream and 10 industrially produced ice-cream samples.

KEY:

LPI: Locally produced ice-cream

IPI: Industrially produced ice-cream.

Table 2:

Mean bacteria count obtained from both locally produced and industrially produced ice-cream samples.

\begin{tabular}{|l|l|l|}
\hline Samples & Range $(\mathrm{g})$ & Mean $(\mathrm{g})$ \\
\hline LPI & $1.4 \times 10^{4}-3.0 \times 10^{4}$ & $2.0 \times 10^{4}$ \\
\hline IPI & $3.0 \times 10^{3}-8.8 \times 10^{3}$ & $5.3 \times 10^{3}$ \\
\hline
\end{tabular}




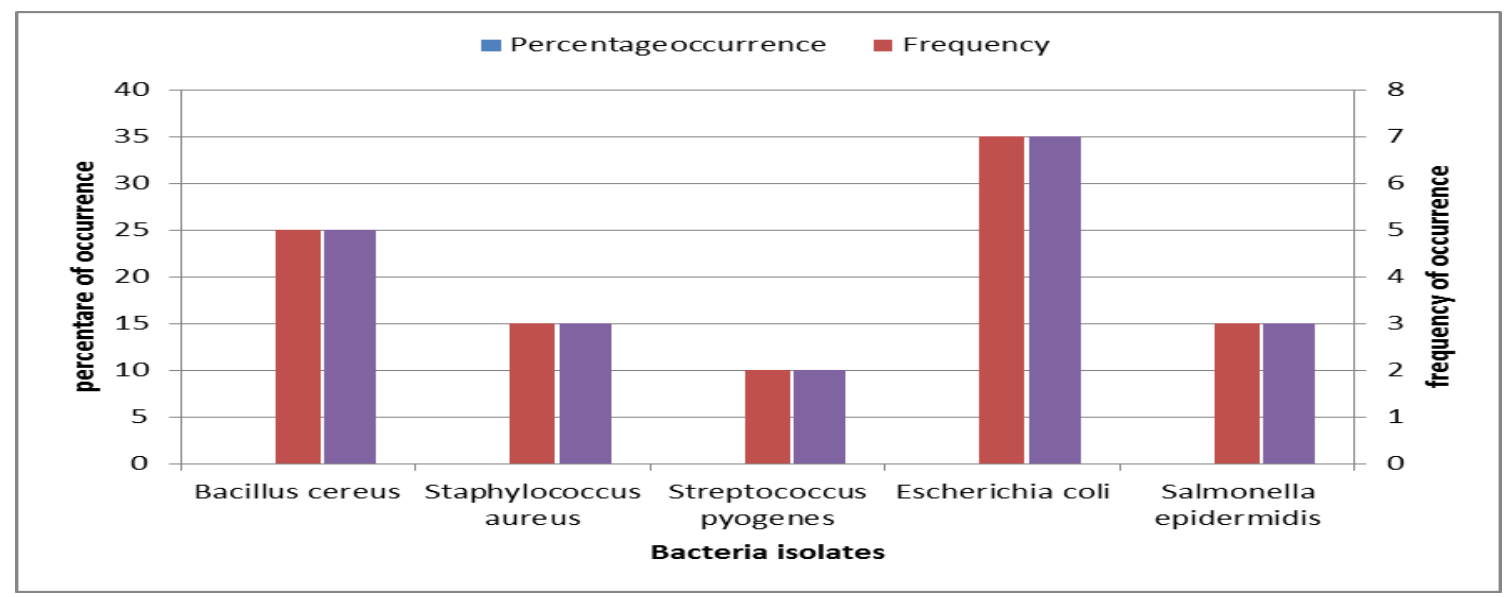

Fig: 3 Frequency and percentage occurrence of the different bacteria isolated from locally produced ice-cream samples.

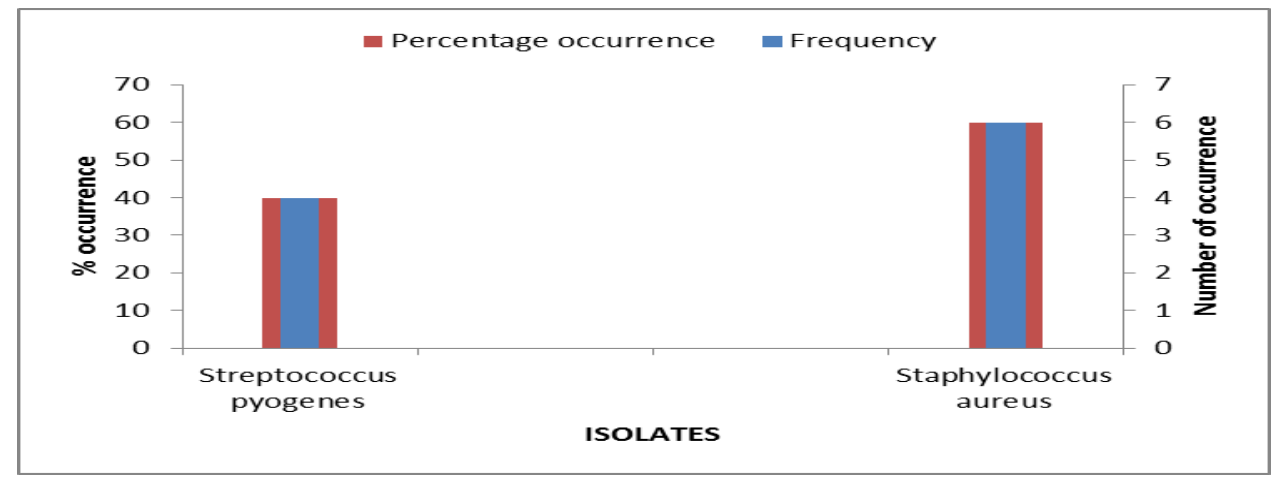

Fig. 4 Number of occurrences and percentage occurrence of the different bacteria isolated from industrially produced ice-cream samples

\section{Discussion}

All the 30 samples of ice-cream examined showed positive for one type of bacteria or the other. Five different types of bacteria were isolated from the samples of ice-cream examined. Results for bacteria counts revealed a mean value of $2.0 \times 10^{4} \mathrm{cfu} / \mathrm{lml}$ of locally produced ice-cream. The count ranged from $1.4 \times 10^{4}-$ $3.0 \times 10^{4} \mathrm{cfu} / \mathrm{ml}$. The values were higher than those obtained from industrially produced ice-cream which ranged from $3.0 \times 10^{3}-8.8 \times 10^{3}$ with a mean count of $5.3 \times 10^{3}$. Bacterial load not more than $10^{5}$ bacteria in icecream reflects good hygiene [26]. The bacteria counts in all the products fell within acceptable limits.Ice creams, a dairy product with high nutritional value and the presence of easily useable fats, carbohydrate and protein is an ideal environment for spoilage by microorganisms. [26].The different types of bacteria isolated in locally produced ice-cream include Bacillus cereus, Staphylococcus aureus, Streptococcus pyogenes, Escherichia coli and Salmonella typhi while in industrially produced ice-cream, the bacteria isolated were Staphylococcus aureus and Streptococcus pyogenes.Analysis of the microorganisms in the locally produced icecream showed that Escherichia coli had the highest frequency of occurrence. This could be because these microorganisms are mostly present in the materials used for ice-cream processing e.g. water used, may be from contaminated river and some of the microorganisms commonly present in the soil could get to the microorganisms commonly present in the soil could get to the ice-cream by contamination. The isolation of Bacillus cereus and Streptococcus pyogenes shows favorable environment within the ice-cream capable of promoting growth of these organisms. The presence of the organism is of health significance as some of them may be capable of causing various ailments of man that may be fatal.Escherichia coli and Salmonella typhi were also isolated from the samples. Coliform being non- spore formers should be susceptible to pasteurization. Their post pasteurization presence in ice-cream may be due to faulty heat process or to post pasteurization contamination by handlers with poor sanitary practices. The level of presence of these organisms in food has been described as index of food hygiene [27]. 
The presence of Staphylococcus aureus in both locally produced and industrially produced ice-cream could be from nose where it is commonly found, hands, skin and clothing of handlers [28] Staphylococcus spp have been known to cause Staphylococcal food poisoning due to ingestion of improperly stored food in which Staphylococcous aureus has grown. Coughing, talking, sneezing produces droplets which could settle on icecream during transportation, storage and retailing. The presence of possible pathogenic organisms in the analyzed ice-cream should be viewed with concern by the consumers, producing company and the Government since food poisoning by Bacillus sp and Salmonella $s p$ is possible through consumption of contaminated icecream.Bryan 1996 reported that proper handling of ice-cream is very important both during manufacturing and storage to prevent outbreak of food borne diseases. Source of contamination could be as a result of contamination from various sources notable handlers during preparation especially under unhygienic condition, also from retailers, most of them do not store ice-cream at the appropriate storage temperature. Even the refrigerated samples are not always maintained between $4^{\circ} \mathrm{C}$ and $6^{\circ} \mathrm{C}$ due to unstable power outage. (Prescott et al, 1999) reported that refrigeration at $5^{\circ} \mathrm{C}$ retards bacterial growth. High temperature therefore favours and encourages bacterial growth which eventually causes spoilage.

\section{Conclusion}

In conclusion, although milk is sterile as it leaves the udder of a healthy cow, it can be contaminated during handling of the farm by a variety of organisms.Ice- cream being a favorite food to many Nigerians and a delicacy rich in glucose, protein and fat, it can be a source of infection if not properly pasteurized and handled. The isolation of Escherichia coli and Salmonella sp suggest that ice-cream could be a source of infections to human by the members of the enteric organism, such as Klebsiella sp, Shigella sp and proteus Sp.Even though the bacteria counts in both ice-cream samples fell within acceptable limits. I am advising consumers to go for industrially produced ice-cream because it is more reliable and hygienic since food poisoning bacteria were not isolated from the sample, even though Staphylococcus sp was present it can be removed by pasteurization.

\section{Recommendations}

Milk should be properly pasteurized to eliminate microorganisms that might contaminate the milk products from infected udder, soil and unclean water.The milk handlers (vendors) should be given a proper orientation on how to produce ice-cream under aseptic techniques, thus the milk mixing, pasteurization, homogenization, ageing and storage. The utensils such as milk pail, bulk containers should be properly washed with clean water.The vendor should ensure that the ice-cream is not exposed to air without cover for flies and blowing air will deposit airborne pathogens into the ice-cream.Consumers should always insist on purchasing properly stored products since the problem of the bacteriological quality lives mainly in handling and storage conditionThe Government should make it a policy that all animals used for dairy production especially the cows be vaccinated against Mycobacterium sp every year, since this specie of organism are responsible for Mycobacterium bovis of cattle and Mycobacterium tuberculosis in humans.

\section{REFERENCES}

[1]. Adams and Moss, Food microbiology, the Royal society of chemistry. Thomas Graham house, Science Park Cambridge UK 1999, 78-106.

[2]. A.E. MalouAduli, and E. Uzochukwu, Yoghurt production for small scale milk processor. NAPRI Bulletin June 1999 Vol. 2, 273.

[3]. S. Akinuli, (1998), Yoghurt drinks manufacturing. Business guide. National Concord May 22 ${ }^{\text {nd }}, 1998, .22$.S.A.Farrag, and, E.H. Marth, 'Interactions between Listeria monocytogenes and other psychotropic bacteria in dairy foods: A review', Food Australia, 44 (1992), 281-286.

[4]. R.T.Marshall, and W.S. Arbuckle, Ice Cream. $5^{\text {th }}$ ed. Chapman \& Hall, New York 1996.

[5]. R.A. Warke, M. Kamat, P. Kamat, P. Thomas, 'Incidence of pathogenic psychrotrophs in ice creams sold in some retail outlets in Mumbai, India’ Food Control, 11 (2000), 77-83.

[6]. C.P. Champagne, R.R. Laing, D. Roy, A.A. Mafu, 'Psycrotrophs in dairy products: Their effects and their control', Crit. Rev. Food Sci. Nutr., 34, 1994, 1-30.

[7]. N.A Daniels, L. Mackinnon, S.M. Rowe, N.H. Bean, P.M. Griffin, P.S. Mead, 'Foodborne disease outbreaks in United States schools', Pediatr. Infect. Dis. J., 21, 2002, 623-628.

[8]. K. Chug, 'Salmonella outbreak from ice cream,' Indian Pediatr., 33, 1996, 976-977.

[9]. T. Djuretic, P. Wall, G. Nichols, 'General outbreaks of infectious intestinal disease associated with milk and dairy products in England and Wales: 1992 to 1996', Commun. Dis. Rep. Rev. CDR Rev., 7, 1997, R41-R45.

[10]. M. Digrak, S. Ozcelik, 'The microbiological quality of ice cream sold in Elazig city', Food, 16, 1991, 195-200.

[11]. M.H. Digrak, H. Tanis, E. Bagci, S. Kitbag, 'Investigation of Listeria, Salmonella, E. Cole, K. pneumoniae in ice cream samples consumed in Kahramanmaras', Gida, 25, 2000, 349-353.

[12]. Evrensel, S.S, E. Gunes, 'Chemical and microbiological quality of ice cream consumed in Bursa', Gida, 23, 1998, $261-265$.

[13]. M. Kivanc, M. Yamac, B. Kunduhoglu, 'The microbiological analysis of ice cream sold in Eskisehir city' Food, 14, 1994, 317322 .

[14]. T. Ozcan, E. Kurdal, 'Research on chemical and microbiological qualities of fruit ice creams were sold in the center of Bursa'. Gida, 22, 1997, 217-225.

[15]. B. Patir, G.A. Oksuztepe, O.O. Ilhak, 'Distribution of coliform bacteria in vanilla and fruit flavouredice cream sold in Elazig', J. Health Sci. Firat Univ., 20, 2006, 1-7. 
[16]. F. Coskun, 'The determination of fecal contamination of strawberry flavored and plain ice cream samples sold in Tekirdag', $J$. Tekirdag Agric. Fac., 2, 2005, 135-142.

[17]. F. Korel, S. Omeroglu and G. Tan, 'The evaluation of quality of packaged an unpackaged ice cream sold in retail markets of Manisa', J. Agric. Fac. Harran Univ., 9, 2005, 11-18.

[18]. M. Adeil Pietranera, S., Narvaiz, P., Horak, C., \& Kairiyama, E. (2003). Irradiated ice creams for immunosuppressed patients. Radiation Physics and Chemistry, 66, 2003, 357-365.

[19]. A.T.M M-E-Elahi, S. Habib, M.M. Rahman, G.I. Rahman, M.J.U. Bhuiyan, 'Sanitary quality of commercially produced ice cream sold in the retail stores', Pakistan J. Nutr., 1, 2002, pp. 93-94.

[20]. G.S Verma, Bacteria quality of some ingredients used in the manufacture of ice-cream. Indian J. Anem. Res 6 1992, 27-50.

[21]. A. Gomez, Microbial content and hygienic conditions of ice- cream sold in Leon Alimentonia 6: 1999, 21-25.

[22]. J. Pelzer J. Michael, D.R Roger, food and waterborne infections of mammals $2^{\text {nd }}$ Ed. USA chap 27, 2000, 436-437.

[23]. M. Cheesbrough (Ed) MED. Lab Manual for Tropical cultures. Butter worth Heinemann Ltd, Johnson Hill Oxford London 2002.

[24]. S.B. Oyeleke, and S. B. Manga, Essentials of Laboratory Practicals in Microbiology. Tobest publisher, Minna, Nigeria. 2008, 3675.

[25]. L. Prescott, M. Harley, P. John and K. Donald, Microbiology $3^{\text {rd }}$ Edition, 1999..

[26]. W.C. Frazier and D.C. Westhoff, Food Microbiology $3^{\text {rd }}$ Edition McGraw Hill Book company, New York, $1978,540$.

[27]. B.C. Hobbs and J.R Golbert (1982); Food poisoning and food hygiene $4^{\text {th }}$ Edition Edward Arnold Limited, London $1982,366$. 